\title{
GEORGE BUTLER E A SECULARIZAÇÃO NO MARANHÃO DA TRANSIÇÃO REPUBLICANA (1885-1892)
}

\section{ROGÉRIO DE CARVALHO VERAS}

Universidade Federal do Maranhão

RESUMO

Trata-se da história do médico e missionário protestante, George William Butler, no período da introdução do protestantismo no Maranhão, em época de transição da Monarquia à República. Embora se conheça a importância da inserção protestante para o processo de laicização do Estado no Brasil, há ainda a necessidade de compreender como essas transformações macrossociais foram vivenciadas no nível microssocial pelos agentes históricos. O objetivo aqui é, a partir da vida deste missionário, entender, sob um novo prisma, as mudanças nos fluxos e refluxos do processo de secularização, no extremo norte do Império. Para tal, serão úteis as contribuições da micro-história, especialmente sua noção de agência e algumas correlações entre insights da antropologia política e acontecimentos da vida de George Butler. Compreende-se que sua trajetória revela as tensões resultantes das coerções e contradições de uma ordem social em crise.

Palavras-chave: Protestantismo. Biografia. Secularização.

\section{ABSTRACT GEORGE BUTLER AND SECULARIZATION IN REPUBLICAN TRANSITION OF MARANHÃO, NORTHEAST BRAZIL (1885-1892)}

This article is about the history of the doctor and protestant missionary, George William Butler. Specifically the years of Protestantism introduction in Maranhão during the transition from Monarchy to Republic. Although the researchers know the importance of Protestant establishment in the laicization process in Brazil, it's necessary to understand how these macro-social transformations were experienced in micro-level by historical agents. The goal in this article is for understanding, from the life of this missionary, of the ebbs and flows of the process of secularization in a new perspective, at the northern end of the Empire. For this task will be useful the concepts of micro-history particulary the notion of agency and some correlations 
between insights of political anthropology and events of George Butler's life. Therefore it is understood that his history reveals tensions resulting from the constraints and contradictions of a social order in crisis.

Keywords: Protestantism. Biography. Secularization.

\section{RESUMEN GEORGE BUTLER Y LA SECULARIZACIÓN EN LA TRANSICIÓN REPUBLICANA EN MARANHÃO, NORDESTE DO BRASIL (1885-1892)}

Es la historia del médico y misionero protestante George William Butler específicamente en los años de introducción del protestantismo en el Maranhão durante la transición de la Monarquía a la República. Aunque se conozca la importancia de la inserción protestante en el proceso de laicización en Brasil, es necesario entender cómo las transformaciones macro-sociales se experimentaron en el nivel micro por los actores históricos. El objetivo es comprender desde la vida de un misionero, de acuerdo con una nueva perspectiva, los cambios de flujos y reflujos del proceso de secularización en el extremo norte del Imperio. Para ello serán útiles los conceptos de micro-historia, especialmente su noción de agencia y algunas correlaciones entre los puntos de vista de la antropología política y los acontecimientos de la vida de George Butler. Se entiende que su historia revela las tensiones resultantes de las restricciones y contradicciones de un orden social en crisis.

Palabras clave: Protestantismo. Biografia. Secularización.

\section{Introdução}

Este artigo analisa a trajetória do médicomissionário americano, George William Butler (1853?-1919), particularmente suas ações no Maranhão entre 1885-1892. O objetivo é, a partir da biografia deste médico e missionário, entender sob um novo prisma as mudanças no nível macrossociológico: os fluxos e refluxos do processo de secularização numa área periférica do país. Alguns estudos têm afirmado a importância da inserção protestante no Brasil para o processo de laicização do Estado,' mas há ainda a necessidade de compreender como essas transformações macrossociais foram vi-

1 Principalmente Vieira (1980) e Ribeiro (1973). venciadas no nível microssocial pelos agentes históricos. Como eles contribuíram para essas transformações? Como reagiram às mudanças nas estruturas de poder nas sociedades em que viveram?

Destaco aqui a importância do nível micro das sociabilidades (amizades/inimizades) para a compreensão das transformações no nível macrossociológico (processo de secularização da sociedade). Para tal, serão úteis as contribuições da micro-história, especialmente sua noção de agência, na qual, apesar das coerções sociais, um indivíduo permanece relativamente irredutivel aos determinantes 
e, de certa forma, capaz de realizar escolhas minuciosas e infinitas, utilizando-se das brechas e contradições dos sistemas normativos. Assim, um indivíduo ora adequa-se às coerções, ora trabalha para transformá-las. Realizo também algumas correlações entre insights da antropologia política e dois momentos que considero fundamentais na trajetória de George Butler no Maranhão: as controvérsias pelos jornais e um conflito com autoridades, por ter realizado um ritual de sepultamento num cemitério católico.

Proponho, portanto, analisar esses eventos a partir do diálogo entre a micro-história e a antropologia política. Creio possível nos apropriarmos de aspectos teóricos tais como: 1) a noção de liberdade do indivíduo possibilitada pelas incoerências da ordem social e normativa; ${ }^{2}$ ) a crítica às concepções universalistas; 3 ) a noção de agência e seu desdobramento lógico na noção de "encenação das diferenças"; 4) a sugestão da consideração etnográfica da metonímia entre amizade/inimizade. ${ }^{3}$

\section{George William Butler e as fronteiras da liberdade}

A chegada de George Butler a São Luís, em maio de 1885, representou a introdução definitiva do protestantismo proselitista no Maranhão. Antes de Butler, dois outros missionários de sua

2 Para Levi é preciso considerar tanto as incoerências entre "normas e práticas", quanto as incoerências entre as próprias normas e, igualmente, pôr em dúvida a homogeneidade das "representações sociais" do grupo, a fim de que não se perca de vista a liberdade do indivíduo e a dinâmica da relação indivíduo-grupo. Enfim, "[...] para todo indivíduo existe também uma considerável margem de liberdade que se origina precisamente das incoerências dos confins sociais e que suscita a mudança social". (LEVI, 2005, p. 182)

3 As temáticas 2, 3, 4 são extraídas do debate sobre a interface entre antropologia e política, segundo as perspectivas de: KUSCHNIR (2007), em “Antropologia e Política". MONTERO, Paula; POMPA, Cristina; ARRUATI, José Maurício (2012), em "Para uma Antropologia do Político. MACAGNO (2014), em "Uma antropologia do político?". instituição ${ }^{4}$ estiveram por um curto tempo ali. Talvez as impressões ${ }^{5}$ destes sobre as elites de São Luís tenham favorecido o envio de um jovem médico e missionário leigo para a região. ${ }^{6}$ Ademais, revelam sobre quais grupos sociais os missionários projetavam suas expectativas de apoio e sobre os quais poderiam direcionar seus esforços proselitistas.

Porém, no Maranhão dos anos de Butler (1885-1892) configurava-se uma luta renhida entre facções de diferentes matizes políticos, econômicos e ideológicos, pela reorganização do aparelho estatal. Em meio a tantos conflitos, o missionário iniciará mais um, tendo como oponente um peso-pesado: o catolicismo ultramontano.?

A primeira expressão pública desse embate ocorreu com a publicação de uma série de artigos no jornal clerical Civilisação, de autoria do Pe. Arthur Cesar da Rocha, durante praticamente todo o ano de 1887, ano da construção e inauguração do primeiro templo protestante na capital. ${ }^{8} 0$ padre publicou uma série inti-

4 Presbyterian Church in the United States (PCUS), conhecida como a Igreja Presbiteriana do Sul.

5 John Rockwell Smith, pioneiro da ação missionária protestante no Maranhão, justificando sua escolha por São Luís, como ponto estratégico de expansão presbiteriana no Nordeste, descreve assim a (alta) sociedade da capital da província: "O povo, isto é, a classe alta de São Luís, são provavelmente pessoas mais alegres que os cearenses, menos beatos e supersticiosos e mais tolerantes ou talvez seja melhor dizer, mais indiferentes em questões religiosas" (BANDEIRA, 1986, p. 5).

6 O Maranhão foi o primeiro campo missionário de George Butler, à época, com cerca de 32 anos, que tinha uma formação médica e jamais frequentado um curso de formação teológica.

7 Refere-se à "nova" face do Catolicismo, após o pontificado de Pio IX (1846-1878), expresso no processo de romanização: no Brasil, significou uma vinculação mais estreita com o papado, independência em relação ao trono e controle intelectual e moral do clero.

8 O mesmo local ainda hoje é templo da Igreja Presbiteriana. De fato, a construção do templo no Maranhão obedecia às restrições de não ter "forma exterior de templo", sem sinos ou torres. Apesar disso, o Pacotilha (02/07/1887) divulgava a inauguração do "templo protestante" (algo, até então inédito no Norte/ Nordeste do país). Assim, Butler repetiu a experiência que fora posta em prática pelos missionários protestantes, tanto no Rio de Janeiro (1874), quanto em São 
tulada "É o protestantismo verdadeira religião fundada por nosso Senhor Jesus Christo?". A tese era que o protestantismo não tem os sinais do verdadeiro cristianismo: a autoridade de ensino, a visibilidade, a perpetuidade, a unidade, a santidade, a catolicidade e a apostolocidade (Civilisação, 26/03/1887).

Os anos de Butler no Maranhão foram também os anos do bispado de D. Antônio Candido de Alvarenga (1878-1898), quando a romanização do catolicismo no Maranhão recrudesceu. As ações de George Butler significaram uma afronta às lideranças católicas locais. A começar pelo fato de que pessoas de projeção gravitavam em seu entorno, como: “[...] Sr. Henry Airlie, cônsul inglês, e do Sr. Jerônimo Tavares, cônsul de Portugal. O Dr. Paula Duarte, primeiro governador do Estado, proclamada que foi a república [sic]. O Sr. Tomas Macdonald, mecânico escocês" (CORTEZ apud FERREIRA, 1959, p. 166).

Observa-se que os ilustres homens são representativos das forças econômicas e políticas. Os cônsules, inglês e português, ${ }^{9}$ representavam o setor empresarial de São Luís. 0 próprio Henry Airlie foi membro ativo da Associação Comercial, durante vários anos, assumindo cargos na diretoria, entre 1882-1888 (VIVEROS, 1954, p. 474 apud SANTOS, 2006, p. 144). Também Butler relacionava-se com atores políticos, como o tenente coronel João Luiz Tavares (esposo de Dna. Polina Jansem Tavares, uma das primeiras batizadas de Butler) e o jornalista e ex-deputado Francisco de Paula Belfort Duarte (esposo da primeira conversão de Butler, Dna. Maria Bárbara Belfort Duarte). Ambos representavam, respectivamente, as

Paulo (1883), quando da adaptação de casas adqui-

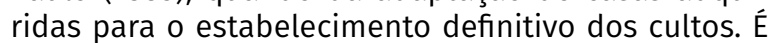
possivel pensar que, apesar dessas restrições arquitetônicas, esses locais definitivos foram chamados de "templos", pelas primeiras comunidades protestantes, como mais uma forma de afirmação identitária e de luta pela legitimidade religiosa.

9 A família Tavares ocupou cargos de direção na Associação Comercial (VIVEIROS, 1954, p. 452 e 474). dissidências dos partidos conservador e liberal, que passaram a fazer propaganda republicana, com a criação de alguns clubes e, mais tarde, compuseram a Junta do Governo Provisório Republicano (REIS, 2007, p. 73).

De fevereiro a outubro de 1887, no jornal semanário católico Civilisação, o Padre Arthur César da Rocha escreveu vários artigos convidando George Butler para debater assuntos teológicos. Como, inicialmente, Butler não aceitou polemizar pelos jornais, os ataques foram sistemáticos. No próprio título da série "É o protestantismo verdadeira religião fundada por nosso Senhor Jesus Christo?" -, percebemos a preocupação do padre em defender o catolicismo oficial e seu espaço de legitimidade social, certamente contra-argumentando o discurso protestante de ser a verdadeira religião cristã. Os artigos têm um tom polêmico, a fim de alcançar um público intelectualizado do qual o protestantismo se aproximava. Por isso, o Padre Arthur enfatiza uma crítica intelectualteológica ao protestantismo, colocando seus argumentos como "provas" racionais:

Depois de ter mostrado com argumentos mais positivos que no protestantismo não existe sob nenhum respeito a unidade da Religião de Jesus Christo, vamos também provar que na communhão dissidente não se encontra outra nota característica da verdadeira Religião: a Santidade. (Civilisação, 27/08/1887, grifo nosso)

Esperava que o ministro protestante apparecesse pela imprensa contestando os documentos que tenho apresentado contra o protestantismo, principalmente por ferirem pontos de que os ministros da seita fazem mais alarde: - o desinteresse, o seu pouco amor ao dinheiro; mas o silencio que tem guardado o Sr. Butler parece ainda uma vez confirmar o prolóquio antigo: Qui tacet consentire videtur [...]. (Civilisação, 10/09/1887, grifo nosso)

Nos seus tratados, o padre Arthur ataca o protestantismo como devaneio intelectual de uma religião individualista, extremamente ma- 
terialista e racionalista, a ponto de levar ao ceticismo, portanto, sem nenhuma base teológica sustentável. Os trechos acima nos permitem entrever uma das estratégias discursivas dos protestantes para se oporem ao catolicismo: "o desinteresse e o seu pouco amor ao dinheiro", alardeado pelos "ministros da seita". A questão da construção da identidade religiosa e das estratégias de combate ao oponente religioso é um dos aspectos que discutiremos adiante.

Apesar dos desafios do padre, Butler não respondeu por meio de longas polêmicas teológicas. Preferiu utilizar-se de notas no jornal Pacotilha, um jornal anticlerical. ${ }^{10}$ Num primeiro momento, lança mão da legislação de tolerância religiosa existente no Império, fazendo publicar essas normas que protegeriam sua prática proselitista, e diz aceitar o debate, desde que "a Bíblia e a Discussão Pública" fossem as armas (Pacotilha, 14/03/1887, p. 3). Enquanto isso, o padre Arthur insistia nos tratados teológicos e no desafio de um debate por escrito. Assim, formou-se um impasse sobre a forma de realizar o debate, acabando por não acontecer.

Uma primeira explicação para tal recusa ao debate escrito, por parte de Butler, talvez esteja na sua insegurança ao manejar por escrito a língua portuguesa e uma melhor confiança na sua habilidade oratória, ou, o que é mais provável, simplesmente ele encontrou uma "saída" sem parecer uma "fuga" constrangedora. O certo é que, no Maranhão de 1887, a indefinição de Butler para o debate expressa um momento de um protestantismo que, apesar de incômodo em razão de seus avanços, ainda se restringia a círculos limitados de indivíduos, e bem poucos com algum prestígio social. A maioria dos membros da igreja é de gente pobre, trabalhadores urbanos e agentes

10 O Pacotilha foi criado no início da década de 1880 para opor-se ao ultramontanismo do Civilisação; seu objetivo era difundir ideais do anticlericalismo na província. comerciais. Há alguns aliados entre famílias e pessoas de projeção,1 mas aparentemente estes não estavam muito dispostos a arriscar suas reputações com a defesa de uma religião estranha, mesmo à maioria dos membros das classes altas. A publicação de artigos anônimos em defesa de Butler e da nova religião no Pacotilha, é uma evidência deste receio que os homens ${ }^{12}$ das elites, simpáticos aos protestantes, tinham de serem socialmente reconhecidos como pertencentes à "seita protestante".

Voltando às publicações de Butler, destacamos a manipulação da ordem legal feita pelo missionário, enquanto representante de uma minoria religiosa desprestigiada. Interessa perceber que, ao simplesmente reproduzir artigos da Constituição e do Código Penal, Butler não se restringe a se apropriar dessas normas como garantias às práticas protestantes, talvez, seu intuito fosse mais ousado, ou, pelo menos, arriscava-se a ser assim interpretado. Uma leitura atenta desta publicação e da conjuntura que a gerou, indica que Butler se utiliza das normas vigentes como arma contra o próprio clero católico. É o que se deduz do próprio título da sua publicação, "A favor dos protestantes", e pela exposição de artigos do Código Penal. Chamo a atenção para este aspecto: não lhe bastou relembrar ao clero as garantias constitucionais, embora limitadas, da liberdade religiosa existentes desde 1824; foi além, isto é, à norma penal que, vale lembrar, tipifica a conduta delituosa e determina a sanção estatal.

11 O historiador David Gueiros Vieira percebe a existência de um verdadeiro clã maranhense que, desde a década de 1860, tomara posições a favor da liberdade de propaganda protestante. Um dos membros deste clã é o Dr. Francisco Belfort Duarte (o mesmo cuja esposa convertera-se ao protestantismo na igreja de Butler) que, já em 1867, havia defendido a venda e mesmo a veracidade das Bíblias protestantes, na Câmara do Império, quando fora deputado, quase 20 anos antes da chegada do missionário Butler ao $\mathrm{Ma}$ ranhão. (VIEIRA, 1980, p. 156-158)

12 Interessante perceber que são as esposas de líderes políticos locais que se convertem à nova religião 
Logo, estamos diante de um sujeito que manipula as contradições internas ao sistema normativo: enquanto o art. 5o da Constituição de 1824 limitava o proselitismo acatólico às casas sem forma exterior de templo,13 outros dispositivos constitucionais e penais permitiam uma interpretação de tolerância da publicidade desse proselitismo. Butler, utilizando-se dessas fissuras normativas, aciona o $\S$ $5^{\circ}$ do art. 179: "Ninguem pode ser perseguido por motivo de religião, uma vez que respeite a do Estado e não offenda a moral pública", e ainda dois artigos do Código Penal, dentre eles o artigo 277, que proíbe "Abusar ou zombar de qualquer culto estabelecido no Império, por meio de papéis impressos... penas de prisão por um a seis mezes e de multa correspondente à metade do tempo" (Pacotilha, 16/03/1887, p. 2).

Portanto, sobre as mesmas leis que várias vezes foram usadas por autoridades católicas para obstaculizar a propaganda protestante, vemos Butler sugerindo uma interpretação e a manipulação que se poderia usar contra a Igreja Católica naquele caso. Pois, diante dos ataques contra ele e o protestantismo, feitos semanalmente no jornal católico, poderiam estas normas serem interpretadas e acionadas para reclamar uma ação das autoridades civis, sob o fundamento do descumprimento legal por parte do clérigo católico.

Além do mais, as controvérsias nos permitem perceber as estratégias de construção da identidade e da diferença entre os oponentes religiosos. Os argumentos em torno da "verdadeira religião cristã" ser a católica, elaborados pelo padre Arthur Cesar, evidenciam o esforço do clero romano de contrapor-se ao impacto das reivindicações da identidade protestante. Por sua vez, a estratégia discursiva da au-

13 “A religião Católica Apostólica Romana continuará a ser a do Império. Todas as outras serão permitidas com seu culto doméstico ou particular, em casas para isto destinadas, sem forma exterior de templo". toidentificação protestante como "verdadeiro cristianismo", constrói, em contradição, uma imagem do catolicismo como uma deturpação do cristianismo, bem próximo ao paganismo.

Os ministros protestantes, ao alardearem ter uma religião desinteressada dos bens materiais, conjugavam-se à crítica, comum à época, aos subsídios estatais e aos pagamentos de sacramentos religiosos ao clero. Se atentarmos bem, ambas as reivindicações da identidade protestante - de ser a verdadeira religião e de não exigir pagamentos pelos seus ritos alinhavam-se bem a uma crítica fundamental, entre os liberais anticlericais, maçons e outros críticos da Igreja Católica, qual seja: a de que o catolicismo seria um fator de atraso da sociedade brasileira, não somente pela relação parasitária legada pelo Padroado Régio, como também pelo obscurantismo intelectual, pois procurava manter a sociedade presa à tradições e crenças "quase-primitivas" (na perspectiva de parte dessas elites modernizantes). Assim, os ministros protestantes, ao construírem sua identidade e a diferença pela proximidade entre catolicismo e paganismo, posicionavam sua religião como uma religião mais compatível com as sociedades civilizadas e modernas.

Por outro lado, a preocupação do padre em racionalizar um argumento irrefutável expressa sua estratégia de combate ao protestantismo. O objetivo é destituí-lo de credibilidade diante dos setores intelectualizados. Reconstruir a imagem do catolicismo perante esses grupos significava mostrar-se intelectualmente superior ao protestantismo, capaz de revelar seus erros e segredos não confessados. Fazendo desfilar citações dos próprios reformadores, o padre mostra-se um erudito e, como representante de um novo clero, mais bem preparado, segundo a ortodoxia romana, e disposto a reconquistar as mentes do século: “Agora apresente-se Sr. Butler e defenda se puder, o fundador da Reforma. Conteste estes 
documentos que ahi ficam estampados, e formule, se for capaz, argumentos que possam destruir os testemunhos que acabamos de nomear" (Civilisação, 27/08/1887 grifo nosso).

Vamos agora ao propositor da polêmica. O Pe. Arthur era um jovem sacerdote formado nas novas orientações ultramontanas. Possivelmente seu comprometimento intelectual com estes preceitos o ajudou em sua rápida ascensão - havia iniciado seus estudos aos 19 anos e com 26, em 1885, já se tornava lente da cadeira de filosofia no Seminário Santo Antônio, onde lecionou até 1889.14 Sua reconhecida competência, como orador e intelectual ultramontano, certamente o habilitou a chamar o ministro protestante à polêmica doutrinária e por várias vezes usou de um tom irônico e galhofeiro sobre as práticas e crenças protestantes: "Sim, parece estar dizendo o Sr. Butler embevecido na sua Bíblia: Que tal? O padre foime a cuia dos quiabos! Por esta não esperava! Que gente perigosa!... Descobrem este segredo que eu julgava desconhecido nestas regiões, sem mais nem menos...! Estes Padres!..." (Civilisação, 10/09/1887).

As falas do Pe. Arthur eram tomadas como institucionais. Seus objetivos eram desacreditar o protestantismo como religião cristã, afirmar que seu racionalismo extremado conduz seus séquitos ao materialismo e ao ceticismo, além de provocar na sociedade as divisões sociais comuns às diferentes "seitas protestantes". Em suma, a estratégia do discurso ultramontano é construir o protestantismo, não somente como desagregador da espiritualidade, mas sobretudo desagregador da ordem social.

Portanto, a série de artigos do Pe. Arthur, pontuando o que seriam as bases autenticamente cristãs da Igreja Católica, revela a preocupação do clero de que o discurso protestante obtivesse ainda maior aceitação entre as

14 Livro de Registros Gerais da Câmara Eclesiástica 18771895, p. 93 - Arquivo Público do Estado do Maranhão. elites intelectualizadas que, embora divididas, compartilhavam de um ambiente de críticas ao clero, ao ultramontanismo e à união Igreja-Estado. Em suma, estamos diante de uma disputa pela legitimidade religiosa perante as elites intelectuais (também, política e economicamente dominantes): a religião tradicional tentando reconquistá-la e a nova religião tentando identificar-se às suas opiniões mais gerais.

A resposta simbólica de Butler ao ultramontanismo foi acionar um critério que já fora utilizado eficientemente por outros missionários protestantes, em outras partes do Brasil, em suas polêmicas com os padres: o uso da Bíblia como fundamento do debate. 0 uso da Bíblia dava aos missionários uma dupla vantagem simbólica: primeiro provavam que suas Bíblias protestantes não eram falsas, como alegavam seus opositores ultramontanos; ${ }^{15} \mathrm{se}-$ gundo, apelavam para um sentido racionalista e individualista, bem ao gosto dos homens de pensamento da época, por meio da ideia do livre exame da Bíblia, a fim de comprovar os "erros e enganos" do catolicismo. A partir disso, a prédica protestante afirmava que qualquer indivíduo, ao ler a Bíblia com o uso da sua razão, era mais autorizado em matéria de religião do que os padres, a tradição da Igreja e mesmo os Papas.

Dessa forma, a presença do missionário protestante forneceu aos setores liberais, anticlericais, mais radicalmente críticos da ordem monárquico-católica, uma transformação simbólica nada desprezivel: a legitimação religiosa da crítica ao ultramontanismo e ao poder da Igreja no Estado Imperial. A própria presença do missionário protestante na província passaria a ser arma política na defesa da separação Igreja-Estado, nas lutas entre os grupos políticos-ideológicos locais. Assim como em outras províncias, a presença do gru-

15 Para isso utilizavam versões católicas. (LÉONARD, 1981, p. 123) 
po protestante conduziu ao crescimento da demanda por um espaço público laicizado, ou seja, onde diferentes religiões, igualmente legítimas, concorrem pelos fiéis sem que qualquer uma delas possa dispor do braço do Estado para defender seus interesses ou eliminar o concorrente.

Em meio a essas lutas pela transformação e resistência macrossociais, em sua expressão local, um fator fundamental foi a personalidade e as ações de George Butler. Através de suas práticas e escolhas estratégicas, mais do que da atividade polemista nos jornais, a transformação simbólica aludida acima fez-se acompanhar de implicações concretas na realidade social, como a luta pela redefinição do espaço público através das ações de Butler, entre as quais, destaca-se, a reivindicação pelo direito à sepultura de uma falecida protestante, em cemitério público administrado pela Igreja Católica.

\section{Um sepultamento acatólico: um embate pela secularização do espaço público}

Após quase um ano de embates pelos jornais, no ano seguinte, início de 1888 , Butler toma uma atitude ainda mais confrontadora: realiza ritos protestantes de sepultamento em cemitério católico. Este acontecimento encontra-se em um documento da Arquidiocese do Maranhão. É um requerimento de 26 de março de 1888 , do Bispo Antonio Candido de Alvarenga ${ }^{16}$ ao Presidente da Província, Desembargador José Bento de Araújo, para que este tomasse providências contra o Sr. George Butler:

[...] participando-me que já por duas vezes se tem apresentado no cemiterio sob a administração da mesma Santa Casa um Senhor George Butler, que se diz Ministro de uma seita protestante, para nesta qualidade funccionar nos

16 Fonte: Bispo Diocesano/Presidente da Província 1878-1901 - ARQUIVO PÚBLICO DO ESTADO DO MARANHÃO enterramentos de pessoas que também se diz pertencerem a essa seita, a fim de que V. Exa.., como provedor da Santa Casa da Misericordia, se digne providenciar como julgar conveniente, em ordem a fazer cessar este abuso, que constitue uma affronta aos sentimentos religiosos $d a$ população desta cidade, visto que o cemiterio à Cargo da Santa Casa é um cemiterio Catholico, e como tal não podem ser nelle sepultados cadaveres de pessoas que tiverem pertencido a seitas hereticas. (grifo nosso)

A narrativa a seguir é do capelão da Santa Casa, testemunha ocular dos ritos de sepultamento realizados por George Butler, anexada ao requerimento do Bispo:

Cópia: Capellania da Santa Casa da Misericordia do Maranhão 26 de março de 1888. Ex ${ }^{\mathrm{mo}}$. Revmo. Senr. julgo de meu dever levar ao conhecimento de V. Ex ${ }^{a}$. Rev ${ }^{m a}$. a tristissima ocorrência que se deu no Cemiterio da Santa Casa da Misericordia no dia 24 do corrente mez, de haver o Senr. Jorge Butler, que se diz ministro protestante, acompanhado o cadaver de uma mulher, que se julga ser protestante, e com grande ostentação fez os ritos de sua seita, apesar das minhas advertências, em presença de vários dos seus sequazes. Devo ainda ponderar a V. Exa ${ }^{a}$. Rev ${ }^{m a}$ que é este o segundo facto que se dá; parecendo que há proposito da parte do dito Senr. Butler provocar qualquer conflito ou ao menos desmoralizar-me no exercício do cargo de capellão da Santa casa da Misericordia. (grifo nosso)

Penso que este evento seja passivel do tipo de abordagem denominada por Gluckman como "análise situacional" (1987). Para tal é preciso considerar os comportamentos dos atores como inseridos num repertório padronizado capaz de exprimir os conflitos e tensões advindas das mudanças sistêmicas. Para Paula Montero et. al., "O uso desses repertórios depende do tipo de inserção do personagem nas relações sociológicas e da potencialidade do padrão para expressar conflitos e interesses relativos àquela posição" (2012, p. 12).

Assim, um enterramento acatólico em "campo santo" católico ressalta a luta pela 
pluralização religiosa da sociedade, com efeitos sobre a secularização dos cemitérios. Sabemos que se desenrolava à época uma luta, encampada por políticos liberais, intelectuais anticlericais, positivistas e maçons, pela secularização dos cemitérios, tornando-os públicos e havia uma legislação que permitia a pessoas acatólicas $^{17}$ enterrar seus mortos, mesmo em cemitérios ainda sob o controle da Igreja.

0 documento nos possibilita ver como o médico-missionário soube mais uma vez se aproveitar das fissuras legislativas e manipulá - las a seu favor para expor suas práticas rituais como religião legítima, tal qual o catolicismo. Evidentemente, com resistências. O embate entre Butler e o padre capelão nos leva a considerar que, no final do século XIX, a ideia de "espaço público" ainda está em gestação.

Consideremos, então, a advertência que Kuschnir (2007) faz aos estudos antropológicos da política: não tomar como universais e atemporais categorias próprias da política moderna, ou seja, não tomar como normativo e necessário um determinado desenvolvimento histórico, como a "secularização"; daí o caráter conflituoso e em aberto sobre os destinos da relação Igreja-Estado. Em meio a soluções mais conciliadoras com a Igreja Católica (concedendo a ela a administração de cemitérios públicos) e/ou a não efetivação das normas de destinação de espaços para acatólicos, a ação de Butler rompe com certa acomodação/ tensão local dos poderes. Ela torna concreta a reivindicação por um "espaço público" de fato, ou seja, laico, representado pelo "direito ao lugar" de descanso eterno. Mas certamente continha riscos, especialmente de uma reação oposta, baseada na moral (valores culturais)

17 "O mesmo decreto de 17 de abril de 1863, que constituiu durante muito tempo o estatuto dos não católicos brasileiros, estabelecia que seus nascimentos e sepultamentos seriam registrados nos cartórios de paz e que os cemitérios públicos comportariam um 'lugar separado' para suas sepulturas”. (LÉONARD, 1981, p. 54) de boa parte da população, possivelmente, até mesmo dos seus aliados.

Essa perspectiva nos sugere a questão do grau de (des)acordo sobre os limites da secularização da sociedade e do próprio sentido de modernidade entre os missionários americanos e seus aliados brasileiros, estes geralmente interessados na modernização material de tipo americana, mas não necessariamente na sua modernização política.

Voltando ao documento, parece que a retórica do Bispo Antônio tenta disfarçar seu receio de que o Presidente da Província não interfira para "fazer cessar este abuso" em favor da Igreja. A ponto de lançar mão de um instrumento de pressão, lembrando-lhe de suas funções legais "como provedor da Santa Casa". Apesar da pressão do Bispo, tanto Butler quanto o Presidente da Província sabiam que as leis do Império já não permitiam uma interpretação tão favorável aos administradores católicos. Ainda assim, Butler estava ciente de que essa "jogada" continha riscos, por isso procurou minimizá-los, como veremos adiante.

Para esta análise é importante a noção de agente, ou seja, como os agentes se constroem por meio de processos simbólicos de legitimação e seu desdobramento, a noção de "encenação" (MONTERO et. al., 2012, p. 30). Segundo Montero et. al., na questão da encenação das diferenças e de sua negociação, há uma mudança conflituosa e um crescimento da atenção pública do problema que, conforme o poder de generalização das reivindicações por parte dos agentes situados, poderá converterse numa demanda por direitos, por reconhecimento na "esfera pública" (MONTERO et. al., 2012).

Neste caso concreto, considerar esses ritos de sepultamento como uma "encenação das diferenças" parece-me adequado para pensar o processo de produção e apropriação da diferença religiosa e da busca de legitimidade 
da diferença. Porém, não é uma reinvindicação dirigida ao Estado, solicitando um "reconhecimento" ou uma "normatização" da convivência, exatamente por que as normas já existem. A reivindicação de legitimidade nessa "encenação" - diferentemente das polêmicas nos jornais analisadas acima (cujo objetivo é obter a adesão das elites intelectuais) - é dirigida ao próprio opositor, a Igreja Católica, diretamente e, indiretamente, à sociedade em geral, que recebia uma nova religião e poderia, pela expressão pública dos seus ritos, conhecê-la e (re)conhecê-la como legítima.

Essa interpretação ajuda a explicar a ousadia de Butler em realizar pela segunda vez "com grande ostentação" os ritos e "em presença de vários dos seus sequazes", não exatamente para desmoralizar o capelão "no exercício do cargo", sim para apresentar-se como "Ministro" protestante. O próprio uso do termo "ministro" é expressão dessa busca de reconhecimento do adversário, como uma religião cristã legítima, ${ }^{18}$ e que poderia competir abertamente não só pelas almas mas também pela representação legitimadora da nova ordem social em gestação. É sobretudo isso que pretendia a "encenação" de Butler. Vejamos, pois, o desenrolar dos acontecimentos.

No dia seguinte ao recebimento do ofício enviado pelo Bispo, o presidente da província dirige uma reunião da Mesa Administrativa da Santa Casa da Misericórdia, onde o assunto foi discutido. Depois de um breve relato do ocorrido, basicamente como o conhecemos, surge uma informação surpreendente, cito:

O Exmo Snr. Provedor [o presidente da província], depois de haver comunicado a Meza que o Ministro protestante o procurara para explicar o seu procedimento em relação aquelle facto $e$ reclamar uma area no Cemiterio própria para o enterramento dos cadaveres daqueles que

180 termo ministro era também usado pelos agentes eclesiásticos católicos, para designar aqueles que pregavam e ensinavam o evangelho. professão a religião protestante apresentou um officio que the endereçou o Exmo Snr. Bispo Diocesano acerca da conveniencia de estabelecer-se aquela para as inhumações dos que se finarem fora do grêmio da Religião Catholica. Discutido o assunto pelos senhores presentes foi resolvido que ao Exmo Snr. Bispo se respondesse que a Santa Caza, nos termos de seu compromisso e regulamento do Cemiterio tomava as necessárias providencias no sentido de fazer manter em respeito os preceitos religiosos recomendáveis pelo Snr. Exmo o mesmo Bispo Diocesano. (Sessão Administrativa em 27 de março de 1888) $)^{19}$

Aqui, vemos um Butler que vai ao Presidente da Província pedir nada mais que o cumprimento da lei. Porém, o aspecto decisivo no caso, que lançou a Mesa Administrativa da Santa Casa na ambiguidade e indecisão foi o próprio reconhecimento do Bispo da "conveniencia" de se cumprir a lei. O mesmo Bispo que, após o acontecimento, solicita ao presidente da província "a fazer cessar este abuso", certamente não esperava que a concessão legal, que havia admitido como "conveniente", 20 seria o espaço normativo suficiente para encorajar Butler a realizar seguidamente, e "com ostentação", rituais de sepultamento de protestantes.

Por outro lado, a ousadia de Butler não pode ser compreendida apenas como uma manipulação das fissuras legislativas, mas também uma tentativa de apresentar a sua religião como possível de ser compreendida e adotada pelos brasileiros. Assim, ele realiza o sepultamento, depois vai ao Presidente da Província "explicar o seu procedimento em relação aquelle facto". Ou seja, na sua pers-

19 Livro de Atas da Santa Casa da Misericórdia do Maranhão - Arquivo Público do Estado do Maranhão.

20 Possivelmente essa admissão do Bispo sobre a conveniencia expressa o crescimento do conflito e das negociações entre os setores liberais-anticlericais e os clérigos católicos, pela restrição dos poderes da Igreja sobre os espaços públicos, principalmente após o estabelecimento de uma concorrente, a igreja protestante. 
pectiva e no agenciamento que ele procura fazer dos códigos culturais, a proibição poderia se aplicar a "seitas heréticas", mas não ao protestantismo, que busca se apresentar, nesses primeiros anos, como um concorrente legítimo ao catolicismo, exatamente por ser uma religião cristã tal qual seu opositor. Portanto, esses sepultamentos, em certa medida, são uma resposta, através de atos, aos ataques do ano anterior, dos artigos no Civilisação, questionando o fundamento cristão do protestantismo.

A narrativa desse evento e de seus desdobramentos também permite-nos refletir sobre o que Macagno (2014, p 178) sugere como a necessidade de estudar a "transitoriedade dos laços sociais". Aqui, voltamos nossa atenção para o esforço contínuo dos grupos de reforçarem a coesão através dos pequenos ou grandes ritos de agregação/separação, ante a contínua ameaça da traição.

É interessante perceber que, para a família da morta, aquele embate pelo sepultamento em cemitério católico, significaria uma gratidão duradoura àquele ministro protestante, pois assim, evitava-se que a convertida à nova religião fosse sepultada distante dos túmulos familiares ou mesmo em terreno destinado aos indigentes. Mais interessante foi descobrir, pelo jornal Pacotilha (24/03/1888), que a mulher "rapariga de nome Amália" era "da casa do sr. dr. Paula Duarte" - o principal líder do partido republicano. Ou seja, Butler assumia o risco de retaliação, a fim de consolidar a fidelidade e o apoio de um importante líder político.

Assim, ao aguçar a percepção etnográfica por meio da metonímia entre amizade/inimizade, obtém-se uma compreensão menos idealizada (mais empírica) das relações do missionário com aqueles membros das elites políticas, econômicas e intelectuais da cidade, como Paula Duarte, Henry Airlie e literatos como Aluísio Azevedo e Sousândrade. ${ }^{21}$ Todos esses aliados das classes cultas e abastadas certamente deram a Butler uma percepção de que poderia ousar na atividade proselitista. Todavia, nenhum destes tornou-se membro da igreja protestante, no máximo, como no caso de Henry Airlie e Jerônimo Tavares, admitiram-se como simpáticos da causa, amigos dos protestantes e até mesmo contribuíram financeiramente na construção do templo, mas em nenhum momento os vemos arriscar seus prestígios sociais acompanhando Butler em seus enfrentamentos, muito menos tomando a frente, em sua defesa, perante as autoridades civis e religiosas. A maioria deles era afeita às modernas ideias liberais-anticlericais, via positivamente a inserção protestante como alternativa religiosa para civilizar o povo e controlá-lo, como também mais adequada à modernização técnica do país, mas não necessariamente acreditava que essa fé seria para eles. Sua aliança com o protestantismo duraria enquanto essa representação genérica do protestantismo com a modernidade se sustentasse.

Possivelmente, essa percepção do frágil apoio desses membros das elites trouxe a Butler o receio de aprofundar-se na polêmica teológica pelos jornais, já que não tinha o preparo teológico suficiente, preferindo, como vimos acima, devolver o desafio propondo uma "discussão pública" oral. Percebeu que, se respondesse por escrito, disponibilizaria suas ideias ao sabor da crítica e correria o risco de perder o trunfo da identificação da religião protestante à racionalidade moderna e, consequentemente, perder alguns aliados/simpatizantes. Sua atitude foi retrair-se e orar. ${ }^{22}$

21 Os literatos partilhavam com o missionário as páginas do jornal anticlerical Pacotilha.

22 "[...] desde a controvérsia pelo jornal em abril e a perseguição subseqüente, nós temos uma reunião de oração em minha casa toda noite, menos naquelas em que há trabalhos de prédica" (FERREIRA, 1959, p. 167) 
Esperou, então, o ano seguinte surgir para responder, não em palavras, mas em ações através dos ritos de sepultamento - sobre a legitimidade cristã e modernizadora do protestantismo.

Por fim, este acontecimento - um sepultamento acatólico - mostrou-se passivel de uma "descrição densa", por constituir-se de uma complexa trama social que apenas iniciamos seu desvelo. Certamente as reflexões da Antropologia Política e seus recentes debates na academia brasileira ${ }^{23}$ mostram-se promissores para uma melhor compreensão do "acontecimento", celebrado, nas últimas décadas, pela historiografia, em seu "retorno". Considerar esse rito de sepultamento revelou-se útil à pretensão de estudar as microssociabilidades existentes nas lutas pela secularização e a pluralização religiosa no Brasil.

\section{Considerações finais}

Neste artigo vimos que nas contradições e fissuras objetivas (políticas, ideológicas, legais) da ordem social, um gênio da prática cotidiana, como Butler, negocia, manipula, usa e trans-

\section{Referências}

BANDEIRA, Abderval P. Igreja Presbiteriana de São Luís: um século de lutas e vitórias -subsídios históricos. São Luís, 1986.

FERREIRA, Edijéce M. A bíblia e o bisturi. 2. ed. São Paulo: Casa Editora Presbiteriana, 1987.

FERREIRA, Júlio Andrade. História da Igreja Presbiteriana do Brasil. v. 1. São Paulo: Casa Editora Presbiteriana, 1959.

GLUCKMAN, Max. Análise de uma situação social na Zululândia moderna. In: FELDMAN-BIANCO, B. (Org.). Antropologia das sociedades contemporâneas. São Paulo: Global, 1987. p. 277-344.

23 Refiro-me ao debate entre os pesquisadores MONTERO et. al. (2012) e MACAGNO (2014). forma os elementos dessa ordem. Compreendemos que a introdução do protestantismo no Maranhão não foi apenas facilitada por processos macrossociais, como a secularização. Esses processos também se tornaram efetivos na realidade dessa sociedade, pelas ações desse sujeito histórico, desafiando a ordem, ao forçar os limites da liberdade religiosa.

Esse estudo biográfico nos permitiu sondar mais de perto os sentidos dos comportamentos, das identidades, dos gestos e atitudes deste e de outros atores sociais. Vislumbrarmos algumas contradições de sua personalidade e o impacto delas sobre suas escolhas. Por outro lado, focar as lentes sobre uma trajetória possibilitou compreender melhor como um indivíduo encontra espaço para sua autonomia, ainda que cerceado por sistemas sociais aparentemente coesos e estáveis.

Enfim, restituir o lugar do agente nesse processo que é predominantemente lido pelo viés da transformação jurídico-política e macroestrutural da separação Igreja-Estado é uma tarefa ainda distante de estar concluída, mas na qual este texto pretende ser uma contribuição.

KUSCHNIR, Karina. Antropologia e política. Revista Brasileira de Ciências Sociais, v. 22, n. 64, p. 163-167, 2007.

LÉONARD, Émile-Guillaume. 0 protestantismo brasileiro: estudo de eclesiologia e história social. 2. ed. Rio de Janeiro: JUERP; São Paulo: ASTE, 1981.

LEVI, Giovanni. Usos da biografia. In: AMADO, J.; FERREIRA, M. (Orgs.). Usos e abusos da história oral. 7. ed. Rio de Janeiro: FGV, 2005. p. 167-182.

MARQUES, César Augusto. Dicionário Histórico-Geográfico da Província do Maranhão. 3. ed. São Luís: Edições AML, 2008.

MACAGNO, Lorenzo. Uma antropologia do político? Análise Social, v. XLIX (1ㅇ), n. 210, p. 163-189, 2014. 
MONTERO, Paula; POMPA, Cristina; ARRUATI, José Maurício. Para uma antropologia do político. Horizonte da política: questões emergentes e agendas de pesquisa, 2012. Disponivel em: <http:/ / www.academia.edu/2455734/Para_uma_antropologia_do_ pol\%C3\%ADtico>. Acesso: 15 ago. 2015.

PEREIRA, Lupércio Antônio. Tavares Bastos, a imigração europeia e o lugar das ideias liberais no Brasil. Diálogos, Maringá, v. 16, n. 3, p. 1085-1110, set./ dez. 2012. Disponivel em: <http://www.redalyc.org/ articulo.oa?id=305526887011>. Acesso: 20 ago. 2015 (on-line)

RIBEIRO, Boanerges. Protestantismo no Brasil Monárquico 1822-1888: aspectos culturais de aceitação do protestantismo no Brasil. Pioneira: São Paulo, 1973.
REIS, Flávio A. M. Grupos políticos e estrutura oligárquica no Maranhão (1850/1930). São Luís: [s.n.], 2007.

SANTOS, Lyndon de Araújo. As outras faces do sagrado: protestantismo e cultura na Primeira República Brasileira. São Luís: Edufma; São Paulo: Ed. ABHR, 2006.

VIEIRA, David Gueiros. 0 protestantismo, a maçonaria e a questão religiosa no Brasil. Brasília, DF: Ed. da UNB, 1980.

VIVEIROS, Jerônimo de. História do comércio do Maranhão 1612 a 1895. São Luís: Associação Comercial do Maranhão, 1954.

Recebido em: 20.01.2016

Aprovado em: 02.03.2016

Rogério de Carvalho Versa é Graduado em História pela Universidade Estadual do Maranhão, mestrado em Ciências Sociais, pela Universidade Federal do Maranhão. Atualmente, é doutorando de História na Universidade Estadual Paulista (UNESP/Assis-SP) e professor da Universidade Federal do Maranhão, campus de Imperatriz. Desenvolve pesquisas nas áreas de Memória e Biografia, História e Antropologia da Religião, com ênfase no protestantismo. E-mail: rogeriveras14@gmail.com

Rua Emílio de Menezes, 572 B, São Francisco, Curitiba-PR; CEP 80510-320 